\title{
Economische argumenten tegen handel met voorwetenschap
}

\author{
Drs. E.H. Rebers
}

\section{Inleidling}

In Nederland is handel met voorwetenschap officieel strafbaar geworden in 1989. Bij juristen bestonden echter vele twijfels over de uitvoerbaarheid van de wet. Deze twijfels namen zeker niet af na de HCS-affaire. Integendeel, er was alom kritiek op het $O M$, die een zo a-typische zalak had uitgekozen om als eerste voor te leggen aan de rechter. Onlangs heeft in Nederland echter voor het eerst met succes een veroordeling plaatsgevonden wegens handel met voorwetenschap (de Weweler-zaak). Bovendien ligt er een nieuw wetsvoorstel van Minister Zalm bij de Tweede Kamer. Ook op dit nieuwe wetsvoorstel is door juristen weer veel kritiek uitgeoefend.' De recente ervaringen met mislukte processen maken duidelijk dat over de juridische aspecten van de wet inderdaad goed nagedacht dient te worden.

Ook onder economen bestaat er een aanhoudende discussie over de vraag of handel met voorwetenschap verboden dient te worden of niet. Het belangrijkste argument voor het toestalan van handel met voorwetenschap is dat het de marktefficiëntie zou bevorderen. In deze bijdrage betoog ik dat dit laatste niet het geval is, hetgeen impliceert dat de economische argumenten dan ook duidelijk in de richting van strafbaarstelling gaan. Juristen hoeven zich mijns inziens dan ook niet meer de vraag te stellen of strafbaarstelling wenselijk is of niet. maar alleen hoe de strafbaarstelling het beste geëffectueerd kan worden.

Drs. E.H. Rebers is verbonden aan het Limburg Institute of Financial Economics (LIFE) en de sectie financiering aan de Universiteit Maastricht.

\section{Handel met voorwetenschap: verwerpelijk of niet?}

Economen zijn het nog steeds niet eens over de vraag of handel met voorwetenschap nou wel of niet strafbaar dient te zijn. Voorstanders van strafbaarstelling beweren dat handel met voorwetenschap schadelijk is voor het vertrouwen in de kapitaalmark ten. Beleggers zouden een gevoel van oneerlijkheid ervaren en dalardoor de markt verlaten, hetgeen ten koste gaat van de licquiditeit van die markt. Bovendien kan het loestaan van handel met voorwetenschap leiden tot perverse incentives voor managers van beursgenoteerde ondernemingen. ${ }^{2}$ Er zijn echter ook auteurs die tegen strafbaarstelling zijn. Zo geeft Rietkerk (1984) twee belangrijke argumenten om handel met voorwetenschap niet strafbaar te stellen. Allereerst betoogt deze auteur dat het de onderneming is die verantwoordelijk moet worden gesteld voor het ontstaan van de informatieasymmetrie. Bovendien, zo vervolgt Rietkerk, bevordert handel met voorwetenschap, gegeven de asymmetrische informatie, juist de marktefficiëntie. Op beide argumenten zal ik nu nader ingaan.

\section{De onderneming is verantwoordelijk}

De redenatie van Rietkerk gaat als volgt. Indien handel met voorwetenschap plaatsvindt, is er blijkbaar op enigerlei moment een situatie ontstaan waarin niet de gehele markt gelijkelijk is geïnformeerd. Aangezien de onderneming geacht mag worden wel over alle informatie te beschikken, is het haar verantwoordelijkheid om de informatieasymmetrie op de markt zo snel mogelijk weg te werken door de informatie aan de gehele markı kenbaar te maken. Hier past echter een drietal nuanceringen. 
Allereerst kan de onderneming uit concurrentieoverwegingen een goede reden hebben om sommige informatie (voorlopig) niet openbaar te maken. ${ }^{3}$ Bezie bij wijze van voorbeeld de situatie waarin de onderneming net een nieuw product heeft ontwikkeld, hetgeen de intrinsieke waarde van de onderneming zeker heeft doen toenemen. Op het eerste oog is het nu in het belang van de aandeelhouders om zo snel mogelijk met deze informatie naar buiten te komen. Immers, het ligt in de lijn der verwachting dat de aandelenkoers door deze aankondiging zal stijgen. Indien echter via deze aankondiging de concurrenten de mogelijkheid krijgen om het nieuwe product ook op de markt te brengen, of in ieder geval sneller dan zonder aankondiging, dan snijdt de onderneming zich daarmee in de eigen vingers. Het positieve koerseffect kan daarmee wel eens teniet gedaan worden.

Daarnaast is het niet per definitie zo dat 'de onderneming' altijd in staat is om de gehele markt op tijd te informeren. Bezie hiertoe het voorbeeld uit de vorige alinea. Indien het nieuwe product bijvoorbeeld ontwikkeld is door één medewerker van de R\&D-afdeling, dan kan men zich goed voorstellen dat deze medewerker eerst een flink aantal aandelen (of nog beter: call-opties) van de onderneming koopt alvorens hij zijn ontdekking aan de onderneming kenbaar maakt. Het is dan mijns inziens moeilijk te verdedigen dat de onderneming, en niet de desbetreffende medewerker. hiervoor verantwoordelijk is.

Als derde moeilijkheid kan genoemd worden dat de informatieverstrekking van de zijde van de ondernemingsleiding in de ogen van de vermogensmarkt niet altijd geloofwaardig hoeft te zijn. ${ }^{4}$ Zo heeft de literatuur over signalering ons bijvoorbeeld geleerd dat de onderneming alleen op geloof waardige wijze 'goede' informatie aan de vermogensmarkt zal kunnen signaleren indien ondernemingen zonder dit goede nieuws het signaal niet tegen lage kosten kunnen imiteren.

\section{Marktefficiëntie}

Een markt is efficiënt indien op ieder tijdstip alle relevante informatie in de koersen is verwerkt. Op die manier is het dan voor geen enkele belegger mogelijk om systematisch een buitengewoon rendement te behalen. Het is gebruikelijk om op basis van het begrip 'alle' informatie drie vormen van efficiëntie te onderscheiden.' Indien alle historische koersinformatie in de koersen is verwerkt, dan is de markt efficiënt in de zwakke vorm. Gaat het niet alleen om historische koersinformatie, maar om alle publiekelijk beschikbare informatie, dan is de markt efficiënt in de semisterke vorm. Betreft het letterlijk alle informatie, dus ook de niet publiekelijk beschikbare, ofwel private, informatie, dan is de markt efficiënt in de sterke vorm.

Efficiënte markten zijn van grote economische waarde. Zij bewerkstelligen immers dat de schaarse economische middelen naar de meest rendabele investeringen worden gealloceerd. Mutatis mutandis geldt dan ook: hoe efficiënter de markt, des te beter. Aangezien nieuwe informatie via handel op de beurs in de koersen wordt verwerkt, kunnen wij handel met voorwetenschap als noodzakelijke voorwaarde beschouwen om de markt efficiënt in de sterke vorm te krijgen. Zo zal bijvoorbeeld bij privaat goed nieuws het aankoopgedrag van insiders ervoor zorgen dat de koers al geleidelijk naar zijn hogere evenwichtsniveau zal kruipen voordat het goede nieuws daadwerkelijk naar buiten komt. Dit is dan ook een argument dat Rietkerk gebruikt om handel met voorwetenschap niet strafbaar te stellen.

Ook hier past echter weer een nuancering. Er zijn namelijk twee belangrijke voorwaarden waaraan moet worden voldaan wil het proces, zoals beschreven in de vorige alinea, ook daadwerkelijk kunnen plaatsvinden. Allereerst zal het bedrag dat insiders tot hun beschikking hebben om te handelen van een behoorlijke omvang moeten zijn, om enig koerseffect te krijgen. Een tweede, hiermee samenhangende voorwaarde is dat er tevens voldoende marktpartijen moeten zijn waarmee de insiders kunnen handelen. Anders gezegd, de markt zal voldoende liquide moeten zijn. Aan de eerste voorwaarde kan, met enige goede wil, wel worden voldaan. Indien handel met voorwetenschap echter niet strafbaar is, komt de tweede voorwaarde. namelijk liquide markten, danig in het gedrang. Dit zal in de volgende paragraaf nader worden toegelicht.

\section{Marktefficiëntie en marktliquiditeit}

Voor vrijwel alle financiële markten geldt in principe 'laissez-faire, laissez-vivre'. In meer financieel-economische termen, het prijsmechanisme is heer en meester, hetgeen zorgt voor een efficiënte allocatie van de beschikbare schaarse 
middelen. Paradoxaal genoeg is er echter wel een aantal randvoorwaarden waaraan moet worden voldaan wil dit principe goed functioneren. Zo zijn een stabiel politiek klimaat en een deugdelijke wetgeving onontbeerlijk. Vanuit de economische wetenschap is vooral benadrukt dat er ook sprake moet zijn van voldoende marktparticipanten, en ook van voldoende en deugdelijke informatie, die bovendien voor iedereen in gelijke mate beschikbaar moet zijn. ${ }^{6}$

Beschouwen wij nu de aandelenmarkt, dan zullen er per definitie altijd momenten zijn waarop sommige mensen beter geïnformeerd zijn dan anderen. Belangrijkste reden hiervoor is het door Berle en Means (1932) krachtig omschreven fenomeen van de scheiding tussen leiding en eigendom in de moderne, beursgenoteerde vennootschap. Anders gezegd. het management van de onderneming, verantwoordelijk voor de dagelijkse leiding van het bedrijf, zal per definitie op sommige momenten meer informatie bezitten dan de gemiddelde aandeelhouder van die onderneming. ${ }^{7}$ In de vorige paragraaf is reeds uiteengezet dat deze informatieasymmetrie bovendien niet altijd zo maar kan worden opgeheven door de informatie publiekelijk te maken.

Aangezien wij dus met deze asymmetrische informatie zullen moeten leren leven, blijft er eigenlijk maar één manier over waarop het goed functioneren van de markt toch gewaarborgd kan blijven. Het principe is heel eenvoudig: iedereen die voorwetenschap heeft dient de markt te mijden. Alleen op die manier blijft gelijke informatie (en dus gelijke kansen) voor iedere marktparticipant gewaarborgd. Men spreekt in dit verband wel over de aandelenmarkt als een fair game. En alleen onder die voorwaarde zullen er altijd voldoende marktparticipanten overblijven, hetgeen een tweede belangrijke economische voorwaarde was voor het goed functioneren van een markt. Dit zal nu verder worden uitgewerkt.

In de microstructuur-literatuur over aandelenmarkten worden vaak drie typen beleggers onderscheiden. ${ }^{8}$ Er zijn twee typen geïnformeerde beleggers op de markt. Het eerste geïnformeerde type is de insider, die in staat is om tegen een bepaalde prijs specifieke informatie over een aandeel te verwerven. Het tweede geïnformeerde type is de professionele belegger, zoals de analist of effectenhandelaar. Ook hij kan informatie over een aandeel verwerven, maar deze informatie zal altijd duurder en van mindere kwaliteit zijn dan de informatie van de insider. Het derde type belegger is de liquidity trader. Deze belegger komt niet naar de markt uit informatieoverwegingen, maar om tijdelijke liquiditeitsoverschotten (en -tekorten) over de tijd te spreiden. Een voorbeeld hiervan is iemand die een ontvangen erfenis in aandelen belegt voor een goede oude dag, de dividenden gebruikt voor consumptieve doeleinden, en plotseling toch weer een gedeelte van zijn aandelen verkoopt ter financiering van een auto.

De beschikbare informatie van de geïnformeerde beleggers wordt alleen in de aandelenkoersen verwerkt indien zij ook daadwerkelijk handelen. Indien bijvoorbeeld een geïnformeerde belegger positief nieuws heeft over een aandeel, zal hij een kooporder plaatsen. De resulterende verhoogde vraag leidt dan, ceteris paribus, tot een verhoogde prijs van het aandeel, overeenkomstig het positieve nieuws. Een positief effect van de handel door een insider is dan ook dat zijn (superieure) informatie in evenwicht in de prijs van het aandeel zal zijn verwerkt.

Echter, het feit dat er een insider handelt impliceert dat de overige beleggers gemiddeld genomen minder winst zullen halen. Een aantal professionele beleggers zal dan ook de markt verlaten, hetgeen betekent dat hun informatie niet in de prijs van het aandeel zal worden verwerkt. Fishman en Hagerty (1992) concluderen dan ook dat het toestaan van insider trading alleen dan de marktefficiëntie verhoogd indien het positieve effect van betere informatie van de insider groter is dan het negatieve effect van minder informatie door het verminderd aantal professionele beleggers dat handelt.

Ook Leland (1992) concludeert dat de professionele beleggers slechter af zijn. De grootste verliezers zijn volgens hem echter de liquidity traders, omdat de aanwezigheid van insiders leidt tot een verminderde marktliquiditeit. Men spreekt in dit geval van een lage marktliquiditeit indien aan- en verkooporders relatief grote prijsveranderingen tot gevolg hebben. Beschouw als voorbeeld de persoon die zijn erfenis in aandelen wil beleggen en daarmee dus de vraag naar aandelen vergroot. Indien de markt meent dat deze extra vraag van insiders afkomstig is, zal de koers extra gaan stijgen. hetgeen betekent dat de liquidity trader zijn aandelen tegen een hogere prijs moet aanschaffen. ${ }^{9}$

De conclusie van Leland dat de liquidity traders de meeste schade lijden door het handelen 
van insiders kan nog verder uitgewerkt worden. In tegenstelling tot de professionele beleggers zullen de liquidity traders de markt op korte termijn niet verlaten. De kapitaalmarkt vervult in ons systeem immers een zeer belangrijke functie bij het spreiden van onregelmatige inkomensstromen. Indien de schade echter te groot wordt zal er zich hoogstwaarschijnlijk een alternatief ontwikkelen en zullen de liquidity traders de markt gaan mijden. ${ }^{10}$ Dat betekent dan dat het totale handelsvolume op de beurs flink zal afnemen, hetgeen een verminderde liquiditeit tot gevolg heeft. En dat betekent dan tevens dat men aan het theoretische voordeel van het toestaan van handel met voorwetenschap helemaal niet meer toekomt; we hebben immers eerder gezien dat een voldoende gewaarborgde liquiditeit een noodzakelijke voorwalarde is om via handel van insiders de koers sneller naar haar juiste waarde te doen tenderen!

De Amerikanen kennen een lange traditie van het instandhouden van een liquide aandelenmarkt. Reeds in 1934 is in de 'Securities and Exchange Act' een regeling opgenomen ter bestrijding van handel met voorwetenschap. De SEC, de Securities and Exchange Commission, het belangrijkste controleorgaan voor de uitvoering van deze wet, bezit hiertoe grote bevoegdheden. Een belangrijk principe van de Amerikaanse wetgeving, 'Abstain or Disclose', kunnen wij na het voorgaande nu goed begrijpen. Indien men private informatie bezit moet men die openbaar maken, en indien dat om welke reden dan ook niet gaat, dan dient men de markt te mijden.

\section{Concluderende opmerkingen}

We hebben gezien dat het karakter van de moderne vennootschap en de met haar verbonden kapitaalmarkt zodanig is dat er altijd wel momenten zullen ontstaan waarop er sprake is van asymmetrische informatie. Omdat het vertrouwen in de markt, en daarmee de liquiditeit en de efficiëntie van die markt, ernstig worden geschaad indien participanten met een informatievoorsprong op de markt aanwezig zijn, dient het Angelsaksische motto: 'Disclose or Abstain" in de praktijk vertaald te worden met 'Abstain', ofwel, in de woorden van Minister Zalm: 'participanten met voorwetenschap dienen de markt te mijden.' Het nieuwe wetsvoorstel speelt daar goed op in. Vrijwel alle betrokken instanties zijn positief over de plannen van Zalm. Vooral ook de plannen voor een meldingsplicht, en zelfs openbaarmaking van die meldingen, blijken een verrassend groot draagvlak te hebben. Hoewel het nieuwe wetsvoorstel vanuit juridisch oogpunt wellicht enige aanpassingen behoeft, dient het mijns inziens toch zo spoedig mogelijk te worden geïmplementeerd. Misschien dat het recente succes van het OM een stimulans is om daar niet meer te lang mee te wachten.

\section{I T E R A T U U R}

Berle, A.A. en G.C. Means, (1932), The modern corporation and private property, MacMillan, New York.

Doorenbos, D.R., (1996, 29 november), De vederlichte bewijslast van misbruik van voorwetenschap, NJB, 2, pp. 1805-1810.

Easterbrook, F.H., (1985), Insider trading as an agency problem, in J.W. Pratt en R.J. Zeckhauser (eds.): Principals and agents: the structure of business, Harvard business school press, Boston.

Fama, E.F., (1970), Efficient capital markets: a review of theory and empirical work, Journal of Finance, 25, pp. 383-417.

Fishman, M.J. en K.M. Hagerty, (1992), Insider trading and the efficiency of stock prices, RAND Journal of economics, pp. 106-122

Glosten, L. en P. Milgrom, (1985), Bid, ask and transaction prices in a specialist market with heterogeneously informed traders, Journal of Financial Economics, 14, pp. 71-100.

Groenhuijsen, M.S., (1995, 14 juli), De Hoge Raad over misbruik van voorwetenschap in de HCS-zaak, NJB, pp. 987-990.

Kyle, A.S., (1985), Continuous auctions and insider trading, econometrica, 53, pp. 1315-1336.

Leland, H.E., (1992), Insider trading: should it be prohibited?, Journal of Political Economy, 100, pp. 859-887.

Moerland, P.W., (1995), Beschermingsmaatregelen, marktliquiditeit en de beurskoers, ESB, nr. 4024, pp. 810-813.

Rietkerk, G., (1984), Effectentransacties door ingewijden, De Naamlooze Vennootschap, pp. 179-184.

Ross, S.A., (1977), The determination of financial structure: the incentive-signalling approach, Bell Journal of Economics, 8, pp. 23-40.

\section{N O T E N}

1 Zie bijvoorbeeld Groenhuijsen (1995) en Doorenbos (1996). 2 Zie bijvoorbeeld Easterbrook (1985) en Ross (1977). 
3 Zie Moerland (1995).

4 Ibid.

5 Zie Fama (1970).

6 In de micro-economie bijvoorbeeld zijn dit twee belangrijke voorwaarden voor het kunnen bestaan van volledig vrije mededinging.

7 Natuurlijk kan iedereen die op enigerlei wijze is betrokken bij de onderneming, zoals account managers bij een bank, medewerkers of de externe accountant, op een goed moment een informatievoorsprong hebben op de gemiddelde aandeel- houder, maar a fortiori geldt dit voor het management.

8 Zie bijvoorbeeld Glosten en Milgrom (1985), Kyle (1985), Fishman en Hagerty (1992) en Leland (1992).

9 Het moge duidelijk zijn dat het hier beschreven principe in werkelijkheid pas optreedt indien meerdere liquidity traders tegelijkertijd een (gelijksoortig) beroep doen op de aandelenmarkt.

10 Een voor de hand liggend alternatief is natuurlijk een buitenlandse beurs waar handel met voorwetenschap wel verboden is. 